\title{
The influence of special graduated weight load in Greco-Roman wrestling on the growth of students' sports results
}

\author{
Nagovitsyn R.S. ${ }^{1}$, Volkov P.B. ${ }^{1}$, Miroshnichenko A.A. ${ }^{1}$, Tutolmin A.A. ${ }^{1}$, Senator S.Yu. ${ }^{2}$ \\ ${ }^{1}$ Glazov State Pedagogical Institute, Russia \\ ${ }^{2}$ Moscow Social Pedagogical Institute, Russia
}

\begin{abstract}
Purpose:

Material:

to assess the impact of a special dosage load in Greco-Roman wrestling on the growth of students' sports results. in research participated 2-3 courses students ( $n=29$, age 16-19 years). The students were divided into two groups: experimental $(E G, n=14)$ and control $(C G, n=15)$. All students were engaged in 4 times per week for 2 hours. Complexes of technical-tactical and psychophysical tasks in the process of each training are realized for $7-7,5$ minutes (with a break of 30 seconds).

Results: $\quad$ A special diagnostic toolkit has been developed to monitor the effectiveness of wrestlers' training in three indicators: physical, intensive and effective. It was revealed that in order to intensify the intensity of the competitive duel, a special loading dosage should be used. It is established that performing exercises with weights without taking into account the special loading dosing leads to a decrease in the speed of the wrestler's movements and to a slowing down of the tempo of the fight. At maximum speed-strength exercise, the athlete's ability to concentrate on coordinating his performance (on the technique of performing the exercise during a competitive duel) is lost.

Conclusions: In case of a maneuver attack, wrestlers play out their opponent with false and preparing attacks. The technique of attacking style requires fast, sharp movements of the body with the capture of the opponent. Therefore, it is advisable to train an athlete in the conduct of a duel using the weight of his own body.

Keywords: training process, students, Greco-Roman wrestling, loading dosing.
\end{abstract}

\section{Introduction}

The growth of sports results in Greco-Roman wrestling causes the improvement of the training process. The growth rates of wrestlers' sports skills include tasks of improving technical and tactical skills and developing psychophysical qualities. Such tasks provide the maximum level of special psychological and physical preparedness of wrestlers.

One of the ways to improve the effectiveness of the educational-training process of training sambo athletes is the use of a complex of psychophysical, technical and tactical exercises. This is provided by a special load metering system [2].

Competitive activity of wrestlers is characterized by actions performed against a background of strong physical and mental stress. The wrestler during the fight must take into account the actions of the enemy. In this regard, the education of psychological qualities (perception of the situation, accurate calculation of time and distance, the ability to counterattack and optimally distribute the load in a duel) are relevant in the theory and practice of athletic training of wrestlers. Therefore, strengthening force and speed endurance, explosive force, coordination of movements are necessary attributes of improving sports skills.

In modern wrestling, the time for a fight has decreased, a break has been added, the process of fighting has started to pass faster and more actively, continuous attacking actions are encouraged [17]. In the Greco-Roman wrestling the duration of the fight is 6 minutes: 2 periods of 3 minutes (break 30 seconds). The summation of points for carried out technical actions is based on the results of the whole match [5].

Latyshev S.V. and Korobeynikov G.V. [10] outlined the issues of theoretical and methodological support for (C) Nagovitsyn R.S., Volkov P.B., Miroshnichenko A.A., Tutolmin A.A., Senator S.Yu., 2017 doi:10.15561/20755279.2017.0606 the training process of wrestlers. The authors prove the necessity of introducing an individual-differentiated approach in the training of athletes. In the practice of conducting a duel in the Greco-Roman wrestling, motor abilities acquire a specialized individual character. They are expressed in the inclination of the fighter to the tempo, force or at the same time speed-power conduct of the duel. Individual style of conducting a duel is seen through the prism of technical and tactical actions: election of an attacking, counterattacking or combined manner of conducting a duel.

Similar proposals for applying a systems approach in training Greco-Roman wrestlers are presented in another study [9]. To increase the functionality of wrestlers during the fight, it is proposed to use an individual approach [16]. Equally important for wrestlers is: optimization of physical activity [35, 37]; selection of adequate tests and pedagogical control of the level of training [30, 38]; planning of training cycles, taking into account the general patterns of training construction [34], morphofunctional features of the organism [39], reactions to physical activity [29]; optimization of nutrition [26, 32]; genetically conditioned personality characteristics $[24,33]$; features of aerobic and anaerobic mechanisms of energy supply to muscular activity [40].

N.A. Alekseev et al. have developed special methods for the development of general and special endurance of wrestlers [1]. The importance of the development of general and special endurance is noted in other studies [22]. E.A. Bavykin for improving endurance offers the use of indices: absolute strength, special endurance and recovery [2].

Kuzmin M.A. and Dorofeeva V.A. suggest to include in the training process complexes of psychological exercises [6]. Kuznecov A.S. and Zakirov D.R. in detail justify the role and importance of methods of psycho-regulation and special pedagogical methods in the training of Greco- 
Roman wrestlers [7]. Similar approaches of psychological preparation are shown in other studies [28,31].

In other studies, questions of tactical and technical training of wrestlers are being raised. Jagiełło W. et al. have presented the process of development and diagnosis of technical skills of athletes in the aspect of monitoring the throwing action of judo athletes [4]. Gierczuk D. et al. have established correlations between the simple reaction time and the technical and tactical actions of elite Greco-Roman wrestlers during the match [25]. Nikooie R. et al. have investigated the physiological determinants of the success of the struggle of Greco-Roman wrestlers [36]. The authors found that muscular strength, muscular endurance and anaerobic ability are the most important variables in the Greco-Roman wrestling. Demirkan E. et al. have established the physical and physiological determinants of success in the Greco-Roman wrestling [23]. Chaabene H. et al. note that to achieve success, training should focus on the development of anaerobic strength and power, aerobic energy, maximum dynamic and isometric force, explosive strength and strength. [21]

Let us highlight the practical orientation in the psychophysical training of Greco-Roman wrestlers.

A.Y. Barkov proposes to focus on technical and tactical actions in a time of shortage of fight. Such exercises increase the speed of performance of techniques and stimulate the athlete's thinking [3]. Sawczyn S. et al. have suggested a technique for training qualified fighters, depending on their predisposition to work in different energy regimes [20]. Jagiello W. and Kruszewski A. suggest to take into account the morphological characteristics of wrestlers in the competitive period [27].

Summing up, we will outline the following: a tendency has been revealed to simplify the technique, to increase the intensity of the duel, to strengthen the technical arsenal of wrestlers, to manifest psychophysical qualities during the duel.

Hypothesis of research. It is assumed that the concentration of efforts in the training process of students on Greco-Roman wrestling to use psychophysical load on a special dosage will positively affect the growth of sports results.

The purpose of the study: to evaluate the effect of a special dosage load in Greco-Roman wrestling on the growth of students' sports results.

In the work is substantiated the application of the activity approach in correlation with the system, individual-differentiated and personality-oriented approaches [11]. The solution of issues is provided by methods of theoretical analysis, practice and experience in the field of training athletes.

\section{Material and methods.}

Participants of the study: in the study took part 2-3 courses students ( $\mathrm{n}=29$, age 16-19 years). The students were divided into two groups: experimental $(E G, n=14)$ and control $(C G, n=15)$. The students in $E G$ have been training with coach R.S. Nagovitsyn (Master of Sports of Russia) and CG - with coach A.T. Lopatin (Master of
Sports of Russia). The choice of a coach and a group was carried out by students on a territorial basis. Classes in the section of Greco-Roman wrestling took place in various gyms and parts of the city. All students were engaged in the sports section of the Greco-Roman wrestling 4 times a week for 2 hours. The participants of the experiment have obtained a consent to participate in this research.

Organization of the study. An experimental research was conducted at the Glazov State Pedagogical Institute (College of Social and Information Technology, Faculty of Pedagogical and Art Education).

In the EG, the main part in training was given to the development of psychophysical qualities and training in technical and tactical actions. The basis of training includes a special dosage load. The repeated method of strictly regulated exercise with weight of own body was applied. In CG was used: a repeated method of strictly regulated exercise with weights.

In the EG was implemented the training process on the author's method of preparing students in the sports section for Greco-Roman wrestling for 3 years. The main aspect of such exercises was based on dosing the psycho-physical load (4 lessons per week). Students spent 3 weeks a month on the author's method (Table 1) and 1 week on the CG program (see below).

Complexes of technical-tactical and psychophysical tasks in the process of each training are realized for 7 7,5 minutes (with a break of 30 seconds). The application of the presented dosage of tasks will allow the wrestlers in the conditions of the competition to "feel" the time period of the fight, maximally concentrate their technical, tactical, physical and psychological potential within 7 7,5 minutes.

The systematic application of these tasks in the training process contributes to the rebuilding of the organism and psyche of the athlete.

The main type of motor activity in the training process of wrestlers is special physical training. The performance of cyclic physical exercises contributes to the development of speed-strength abilities. These qualities developed when performing exercises against a background of high intensity and low volume. Repeated performance of physical exercises of a high-speed character requires the inclusion of psychological qualities: strong-willed efforts, desire, perseverance, and diligence. It is pertinent to assume that the above mentioned psychological qualities do not develop without overcoming efforts on oneself. In training, such psychological qualities as persistence, perseverance, purposefulness, ability to endure and overcome fatigue were brought up. Methods of development of physical qualities are as follows: the method of repeated performance of speed-strength exercises without burdening; method of repeated execution of speed-strength exercises with weights of small and medium weight; the method of exercise performed in the mixed mode of the muscles.

In CG, for 3 years, is implemented the training process according to the following program: three classes for $120 \mathrm{~min}$. each in the gym and one lesson for $90 \mathrm{~min}$. in 
the gym. Particular attention was paid to speed-strength exercises.

In the preparatory part (warming up), the following tasks were solved: organizing a favorable emotional background, establishing contact of the trainer with wrestlers, mobilizing attention and perception, activating vegetative functions, increasing the functional activity of organs and systems, providing mental and functional prerequisites for working the body in the main part of the training.

In the main part of the training of wrestlers, educational, developmental and health issues were solved. Specificity of such tasks is due to the individual skill of students and the stage of Greco-Roman wrestling.

In the final part of the exercise, physical exercises were aimed at reducing the physiological activity of organs and systems, reducing the excessive tension of individual muscle groups, reducing emotional excitement, reducing the degree of activity of autonomic functions and the central nervous system.

The main postulates of this training process: the exercises are performed with an amplitude of movements, close to the competition elements. At the beginning of motor activities, the muscles that actively participate in a duel are loaded. The amount of exercise power is close to the athlete's efforts in the competitive exercise. By increasing or decreasing the mode of the muscles, the wrestler develops either absolute or explosive power. Also the athlete develops power endurance.

The training regimes are as follows: for replenishment of energy costs, wrestlers speed-strength abilities train 1-2 times a week; exercises are performed at a high tempo up to 15 seconds; the rest interval between the exercises is determined until complete recovery: 1-2 min.; between series of tasks up to 10-15 min.; for the development of strength are performed exercises with weights; in one lesson or in a microcycle are alternated speed and strength exercises [14].

To test the effectiveness of the implementation of the training process on the basis of the development of the author's methodology, a special diagnostic tool was developed to monitor the effectiveness of training wrestlers [12]. Three indicators are determined in three levels:

- physical: testing according to the specifications of the All-Russian Complex "Ready for Labor and Defense" (high - gold or silver badge, medium - bronze badge, low - no badge) $[13,14]$;

- intensive: the analysis is carried out on average for all competitive battles of a certain time interval (high - in a competitive duel victory in a "carcass", "purely technical" or an increase in points in the second period of more than 2 points, average - in the competition duel increase or decrease points in the second period not more than 2 points inclusive, low - in a competitive duel, a decrease in points in the second period by more than 2 points);

- effective: the analysis is carried out on average for all competitive bouts (high - 1-3 place in the All-Russian or 1 place at the regional level, average $-2-3$ place at the regional or 1 place at the city level, low $-2-3$ place in the city level or without prizes).

In the process of performing motor actions, physical, functional, psychological and technical-tactical qualities are manifested and developed by athletes. Speed-strength qualities of a wrestler develop when performing exercises against a background of high intensity and low volume. The raise of increase in speed-strength indicators are achieved when performing exercises of a complex nature or train only one physical quality - speed or strength.

Repeated performance of physical exercises of a highspeed character requires the inclusion of psychological qualities: strong-willed efforts, desire, perseverance, and diligence. Education of psychological qualities (perseverance, perseverance, purposefulness, ability to endure and overcome fatigue) determines the effectiveness in a duel.

In the exercises wrestlers use three components: the optimal weight of burdening or working with your own body, the rate of movement and the duration of work. These components are interdependent: reducing the weight of loads leads to an increase in the rate of movement and prolonged work; increasing the weight of load helps to reduce the rate of work and reduce its duration. Therefore, the choice of loads for the development of speed-strength ability in wrestlers is of paramount importance. The individual approach is the most effective for selecting weight of loads [12].

Statistical analysis: the results of the study were processed using the method of mathematical statistics, which was used for quantitative analysis of experimental data. For comparison of EG and CG groups we used the $\mathrm{X} 2$ method. At the end of the experiment, a significantly significant difference $\mathrm{P}<0,05$ was determined in the EG and CG in the intensive and effective indices. According to the physical index, the reliability of differences $\mathrm{P}>0,05$ is not revealed.

\section{Results.}

At the preliminary stage (January-March 2014) and the control phase (January-March 2017), 3 competitions (city, regional and all-Russian levels) were held, in which students from both groups participated (only those students were allowed to compete at the all-Russian level, which won prizes in a regional competition). The results of the experimental study are presented in Table 2 and in Figures 1-3.

Comparative analysis revealed the following:

1. Relatively significant difference $(\mathrm{P}<0,05)$ was determined between the results of the preliminary and control stages in both groups for all indicators and for all levels. This confirms that the implementation of the training process on the experimental and traditional methods positively affects the improvement of physical qualities of athletes. Systematized training increases the intensity of conducting a competitive duel. Training increases the effectiveness of performance at competitions of city, regional and all- 
Table 1. The plan of the weekly training cycle of Greco-Roman wrestlers in the aspect of special loading dosing

\begin{tabular}{|c|c|c|c|c|}
\hline $\begin{array}{l}\text { Day of } \\
\text { week } \\
\text { Level of } \\
\text { intensity }\end{array}$ & Monday / Tuesday & Tuesday / Wednesday & Thursday / Friday & $\begin{array}{l}\text { Friday / } \\
\text { Saturday } \\
\text { Average }\end{array}$ \\
\hline $\begin{array}{l}\text { The content } \\
\text { of training } \\
\text { and dosage }\end{array}$ & $\begin{array}{l}\text { 1. } 15 \text { - } 20 \text { min. - warm up } \\
\text { 2. } 7 \text { min. - to work-out } \\
\text { exercises in the starting } \\
\text { position ( } 1 \text { number) } \\
\text { 3. } 7 \text { min. - to workout } \\
\text { exercises in the starting } \\
\text { position ( } 2 \text { number) } \\
4.7 \text { min. - to work-out in } \\
\text { a pit ( } 1 \text { number) } \\
5.7 \text { min. - to work-out in } \\
\text { a pit ( } 2 \text { number) } \\
6.7 \text { min. - to work-out in } \\
\text { the starting position with } \\
50 \% \text { strength ( } 1 \text { number) } \\
7.7 \text { min. - to work-out in } \\
\text { the starting position with } \\
50 \% \text { strength ( } 2 \text { number) } \\
8.7 \text { min. - to work-out in } \\
\text { a pit with } 50 \% \text { strength } \\
\text { (1 number) } \\
9.7 \text { min. - to work-out in } \\
\text { a pit with } 50 \% \text { strength } \\
\text { ( } 2 \text { number) } \\
10.7 \text { min. - to work-out } \\
\text { of key grips with } 50 \% \\
\text { strength ( } 1 \text { number) } \\
11.7 \text { min. - to work-out } \\
\text { of key grips with } 50 \% \\
\text { strength ( } 2 \text { number). } \\
12.1 \text { ( } 2 \text { ) half - } 7 \text { min. - } \\
\text { power game «stretch } \\
\text { again» } \\
13.7 \text { min.. Stretching }\end{array}$ & $\begin{array}{l}\text { 1. } 15-20 \text { min. - warm } \\
\text { up } \\
\text { 2. } 7 \text { min. - to work-out } \\
\text { key grips with } 50 \% \\
\text { strength ( } 1 \text { number) } \\
\text { 3. } 7 \text { min. - to work-out } \\
\text { key grips with } 50 \% \\
\text { strength ( } 2 \text { number) } \\
4.7 \text { min. - «take out» } \\
\text { in a pit back / reverse } \\
\text { ( } 1 \text { number) } \\
5.7 \text { min. - «take out» } \\
\text { in a pit back / reverse } \\
\text { ( } 2 \text { number). } \\
6.7 \text { min. ( } 6 \text { in } 45 \text { sec. } \\
\text { with rest) - «take out» } \\
\text { in a pit with semi- } \\
\text { strength back / reverse } \\
\text { ( } 1-2 \text { number - change } \\
\text { of partners) } \\
7.7 \text { min.. - training } \\
\text { fight with semi- } \\
\text { strength. } \\
8.7 \text { min.. - training } \\
\text { fight with a change of a } \\
\text { partner. } \\
9.4 \times 7 \text { min.. - round } \\
\text { training ( } 7 \text { stations) on } \\
\text { scheme } 45 \text { sec. - load, } \\
15 \text { sec. - relax } \\
10.7 \text { min.. Stretching }\end{array}$ & $\begin{array}{l}\text { 1. } 15-20 \text { min. - warm up } \\
\text { 2. } 7 \text { min. - to work-out } \\
\text { exercises in the starting } \\
\text { position with } 50 \% \\
\text { strength ( } 1 \text { number) } \\
\text { 3. } 7 \text { min. - to work-out } \\
\text { exercises in the starting } \\
\text { position with } 50 \% \\
\text { strength ( } 2 \text { number) } \\
4.7 \text { min. - to work-out } \\
\text { exercises in a pit with } \\
50 \% \text { strength ( } 1 \text { number) } \\
5.7 \text { min. - to work-out } \\
\text { exercises in a pit with } \\
50 \% \text { strength ( } 2 \text { number) } \\
6.7 \text { min. - training fight } \\
\text { (sparring). } \\
7.2 \times 7 \text { min. }- \text { round } \\
\text { technical training in } \\
\text { starting position ( } 7 \\
\text { stations) under the } \\
\text { following scheme } 45 \text { sec.- } \\
\text { load, } 15 \text { sec.-relax } \\
8.2 \times 7 \text { min.. - round } \\
\text { technical training in } \\
\text { starting position ( } 7 \\
\text { stations) under the } \\
\text { following scheme } 45 \text { sec.- } \\
\text { load, } 15 \text { sec. - relax } \\
9.2 \text { half } \times 7 \text { min.. - power } \\
\text { game «stretch again» } \\
10.7 \text { min.. Stretching }\end{array}$ & $\begin{array}{l}\text { 1. } 15-20 \text { min. - } \\
\text { warm up } \\
\text { 2. } 7 \text { min. - to } \\
\text { work-out key } \\
\text { grips with } 50 \% \\
\text { strength (1 } \\
\text { number) } \\
\text { 3. } 7 \text { min. - to } \\
\text { work-out key } \\
\text { grips with } 50 \% \\
\text { strength ( } 2 \\
\text { number) } \\
7.7 \text { min. - } \\
\text { training fight } \\
\text { with semi- } \\
\text { strength. } \\
4.2 \text { (3) } 7 \text { min. } \\
\text { - training fight } \\
\text { (sparring). } \\
5.3 \times 7 \text { min. - } \\
\text { round training } \\
\text { ( } 7 \text { stations) } \\
\text { under the } \\
\text { following } \\
\text { scheme } 45 \text { sec. } \\
- \text { load, } 15 \text { sec. - } \\
\text { relax } \\
6.7 \text { min. } \\
\text { Stretching }\end{array}$ \\
\hline
\end{tabular}

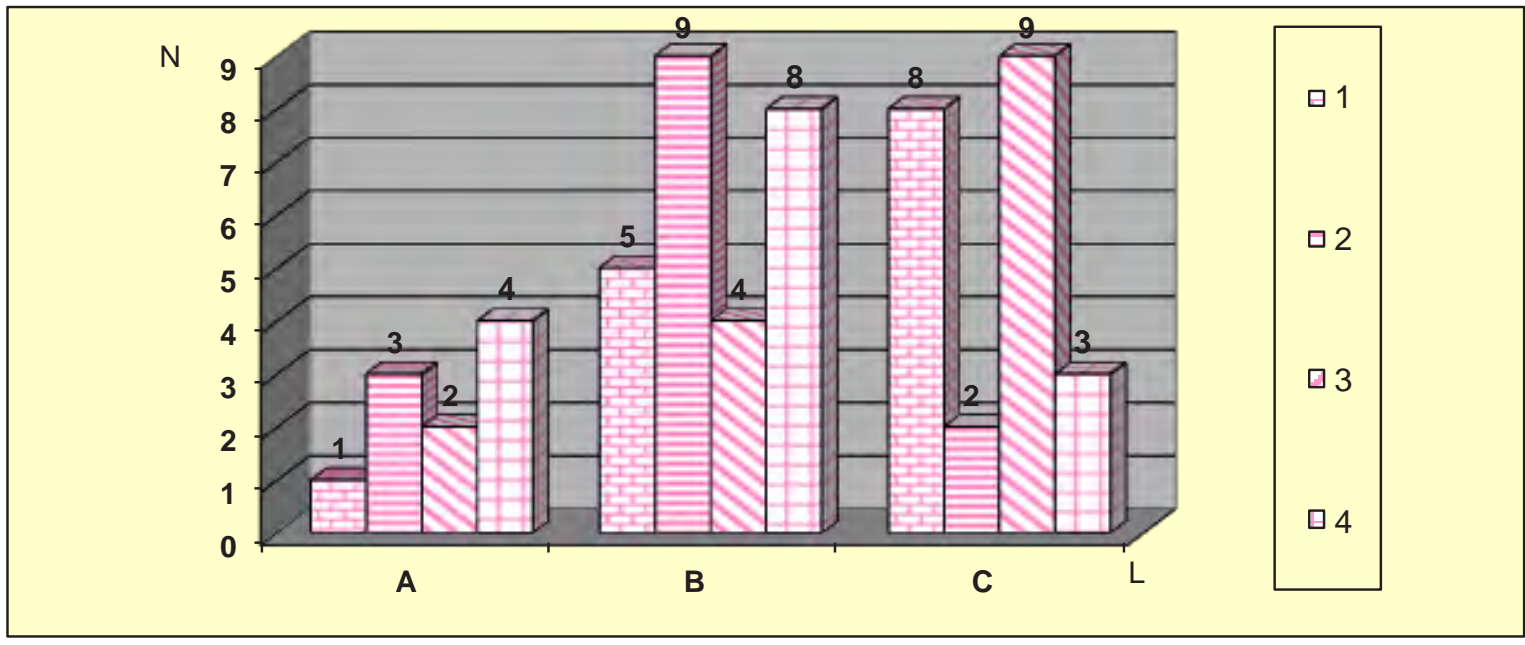

Fig.1. The results of the comparative analysis of EG and CG on the physical indicator: 1 - EG in the preliminary stage, $2-E G$ - at the control stage, 3-CG in the preliminary stage, 4-CG - at the control stage, A - high level, B - average level, $\mathrm{C}$ - low level, D - level, $\mathrm{N}$ - number. 


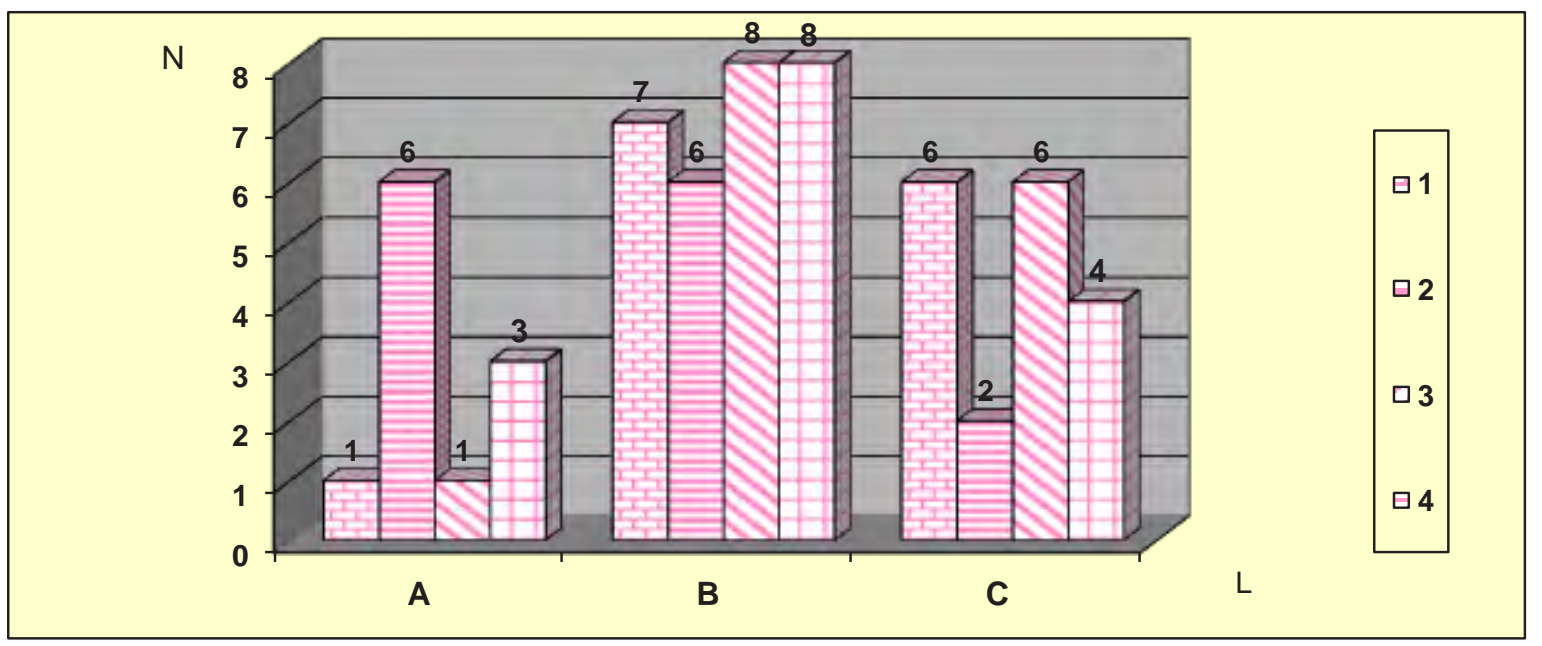

Fig 2. Results of a comparative analysis of $E G$ and $C G$ for the intensive indicator: 1 - EG in the preliminary stage, 2 - EG in the control stage, 3-CG in the preliminary stage, 4-CG in the control stage, A - high level, B-middle level, C-low level, D - level, $\mathrm{N}$ - number.

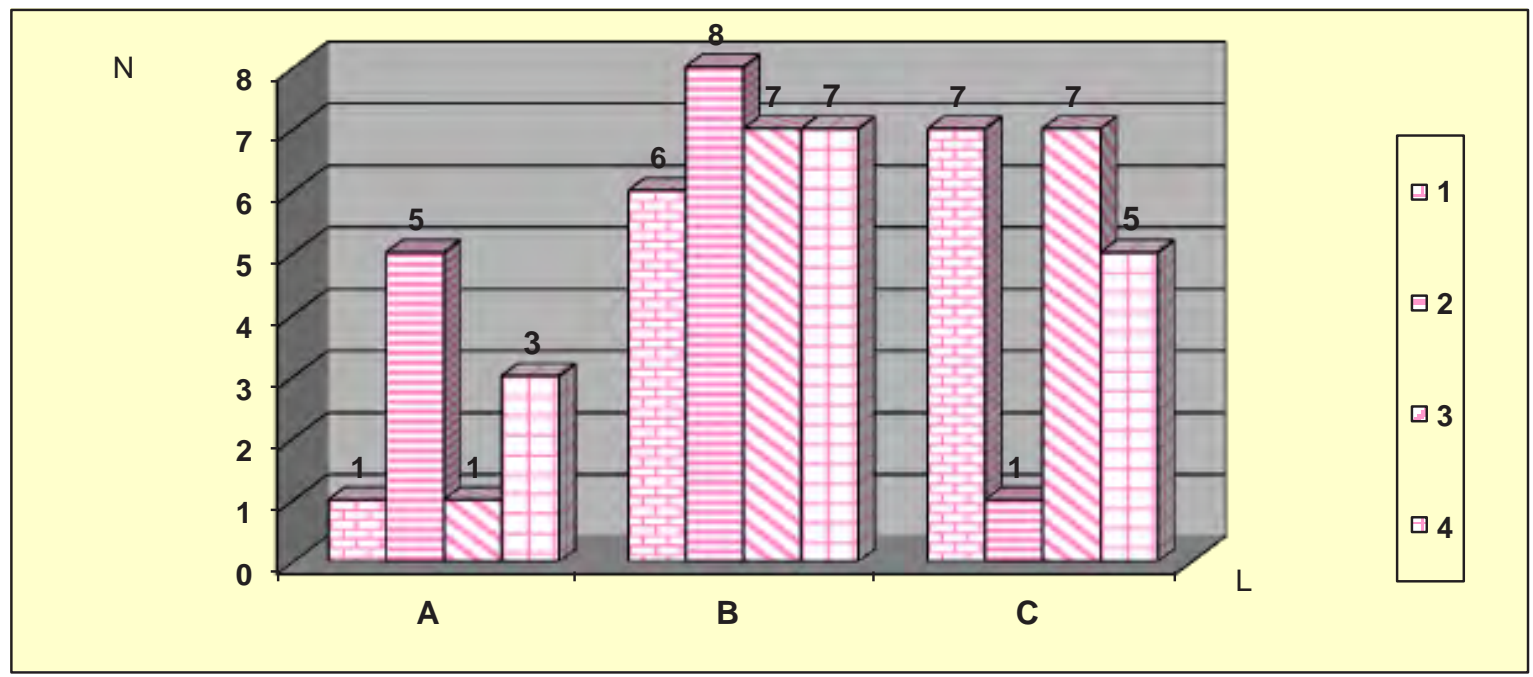

Fig.3. Results of a comparative analysis of EG and CG on the effective score: 1 - EG in the preliminary stage, 2-EG - at the control stage, 3-CG in the preliminary stage, 4-CG - at the control stage, A - high level, B - average level, C - low level, D - level, $\mathrm{N}$ - number.

Table 2. The results of the pilot study at the preliminary and control stages

\begin{tabular}{lllllll}
\hline Parameter & $\begin{array}{l}\text { EG } \\
\text { levels } \\
\text { High }\end{array}$ & Average & Low & $\begin{array}{l}\text { CG } \\
\text { levels } \\
\text { High }\end{array}$ & Average & Low \\
\hline $\begin{array}{l}\text { Preliminary stage } \\
\begin{array}{l}\text { Physical } \\
P>0,05\end{array}\end{array}$ & 1 & 5 & 8 & 2 & 4 & 9 \\
$\begin{array}{l}\text { Intensive } \\
P>0,05\end{array}$ & 1 & 7 & 6 & 1 & 8 & 6 \\
$\begin{array}{l}\text { Effective } \\
P>0,05\end{array}$ & 1 & 6 & 7 & 1 & 7 & 7 \\
$\begin{array}{l}\text { Control stage } \\
\begin{array}{l}\text { Physical } \\
P>0,05\end{array}\end{array}$ & 3 & 9 & 2 & & & \\
$\begin{array}{l}\text { Intensive } \\
P<0,05\end{array}$ & 6 & 6 & 2 & 3 & 8 & 3 \\
$\begin{array}{l}\text { Effective } \\
P<0,05\end{array}$ & 5 & 8 & 1 & 3 & 8 & 4 \\
\hline
\end{tabular}


Russian levels.

2. After the experiment, for all levels in the EG and CG was determined unreliable significant difference at the control stage the physical index. According to the intensive and significant indices was determined reliably significant difference for all levels in the EG and CG. The analysis revealed the effectiveness of the implementation of the author's approach to the intensive and effective indicator. The experimental study had no statistically significant effect on students in the development of physical qualities.

\section{Discussion.}

The analysis of the studies revealed two main directions in the framework of improving the training process in the Greco-Roman struggle. The first direction assigns the main role to the use of speed-strength exercises in training. In the opinion of the authors, this will allow the wrestlers to choose an attacking, counter-attacking or combined style of conducting a duel $[2,6,8]$. The second direction includes the tasks of improving the technical and tactical skills and development of psychophysical qualities. This ensures the maximum level of special psychological and physical preparedness of wrestlers $[15,16]$. The authors of the first direction chose the development of physical qualities as a basis. The main emphasis in the training of wrestlers should be directed to the development of: cardiovascular system, coordination abilities and speedstrength qualities [10].

The characteristics of physical activity include: the quality of the level of efficiency; complex of physical exercises (ratio of exercises); quantitative evaluation (volume) of training work; intensity of training work. The resulted indicators of physical activity should be supervised. This will increase the level of development of physical qualities in wrestlers.

N.A. Alekseev et al. found that the manifestation of speed-strength qualities is due to the athlete's ability to realize high-speed and power capabilities in a specific motor skill [1]. The speed-strength training is based on the athlete's ability to exercise maximum speed and strength in the shortest time [5]. E.A. Bavykin argues that in the Greco-Roman wrestling classes, there is not enough general physical training to develop speedstrength qualities. It is necessary to include in the training process special speed-strength exercises from various sports (kettlebell lifting, power gymnastics, weightlifting, aerobics and others). Consequently, the main type of motor activity for the development of speed-strength qualities in wrestlers is special physical training [2]. S.V. Latyshev has established: the raise of increase in speedstrength indicators can be achieved by a differentiated approach: to train only one physical quality - speed or force [8]. Kuzmin M.A. and Dorofeeva V.A. determined that the raise of increase in speed-strength indicators can be achieved through exercises of a complex nature [6]. An integrated approach to the improvement of the training process in the Greco-Roman struggle must be considered through modeling the conditions of competitive activity.
The model should be based on indicators of psychoregulation and special pedagogical methods [7].

We believe that performing exercises with weights without taking into account the special loading dosing leads to a decrease in the speed of the wrestler's movements and to a slowdown in the pace of the fight. At maximum speed-strength exercise, the athlete's ability to concentrate on coordinating his performance (on the technique of performing the exercise during a competitive duel) is lost.

With a maneuver attack, wrestlers perform an overtraining of the opponent with the use of false and preparing attacks. The technique of attacking style requires fast, sharp movements of the body with the capture of the opponent. Therefore, it is advisable to train an athlete in the conduct of a duel using the weight of his own body. It is also necessary to strictly orient the training process to the temporary conditions of the bout.

The emphasis in training for the development of physical qualities of wrestler averages the technical and tactical actions. For example, the predominance of strength abilities in a fighter contributes to the use in the fight only the tactics of attack. In this case, the fighter puts all his physical power in one go. To defeat the enemy it is enough to use one method or to suppress the enemy. However, a technically prepared opponent can apply maneuvering and retreat. This will allow him successfully counterattack.

Tropin Y.N. et al. substantiates the tendency to simplify the technique, increase the intensity of the duel, strengthen the technical arsenal of wrestlers [19]. Jagiełło W. et al. consider the training of wrestlers in the aspect of monitoring the throwing action [4].

In our opinion, in order to increase the efficiency of the training process, it is necessary to create software and methodical support on the basis of special loading dosing. The methodical unit should include all aspects of the training of wrestlers. In the duel of wrestlers, the main option is a combination attack - holding combinations with false and leading attacks.

The author's technique provides loading dosing taking into account modern requirements of competitive activity. Adapted to a competitive fight, the time for executing a training task allows you to mobilize physical and functional capabilities for rational use of them for a given period of time. The research that we completed complements the work of other scientists on this issue. The results obtained by us have a scientific novelty and special practical significance: the development of the author's methodology for preparing students for Greco-Roman wrestling, taking into account the modern requirements of competitive activities. The materials of our study broaden the notion of the use of a special diagnostic tool for monitoring the effectiveness of training wrestlers.

\section{Conclusions}

To activate the intensity of the competition, use a special loading dosage in the training process. Using the author's methodology will allow to reach a higher quality 
level of the training process, which ensures the growth of sports skills. The diagnostic toolkit and the author's technique can be used at construction of training process in various kinds of single combats.

\section{Acknowledgements}

The publication was prepared within the framework of the scientific project No. 16-16-18003 (Russia).

\section{Conflict of interests}

The authors state that there is no conflict of interest.

\section{References}

1. Alekseev NA, Kutergin NB, Kulinichev AN, Gorbatenko $\mathrm{AV}$. Integrated method development of general and special students stamina involved in the fight. Physical education of students, 2014; 18(3): 3-8. doi:10.6084/m9.figshare. 974476

2. Bavykin EA. Speed and Strength Training as a Base of Special Physical Training in Complex Martial Arts. Theory and Practice of Physical Culture, 2014;2.6. Available from: http://www.teoriya.ru/ru/node/2065

3. Barkov AY. Securing university wrestlers' technical and tactical progress based on competitive performance quality profiling data. Theory and Practice of Physical Culture, 2017;1:53-55.

4. Jagiello Wladyslaw, Dornowski Marcin, Wolska Beata. Basic technical skills (throws) in 17-19-year-old judokas. Physical education of students, 2014; 18(6): 77-80. doi:10.15561/20755279.2014.0615

5. Kaello VV, Bobrov IV, Apoyko RN, Tarakanov BI. Dynamics of Sports Technical Indices of Competitive Activity of Elite Greco-Roman Wrestlers. Theory and Practice of Physical Culture, 2014;2:7. Available from: http://www.teoriya.ru/ru/ node $/ 2066$

6. Kuzmin MA, Dorofeeva VA. Mental adaptation to competitions in martial arts. Theory and Practice of Physical Culture, 2017;5:37-39. Available from: http://www.teoriya. $\mathrm{ru} / \mathrm{ru} /$ node $/ 6574$

7. Kuznecov AS, Zakirov DR. The method of training the wrestlers of the Greco-Roman style on the basis of taking into account the individual and peculiar properties of the psyche. Uchenye zapiski universiteta imeni P.F. Lesgafta, 2013;1(95):72-78. (in Russian)

8. Latyshev SV. Individualization program training in freestyle wrestling. Physical education of students, 2013; 17(6): 3437. doi:10.6084/m9.figshare. 840500

9. Latyshev SV, Korobeynikov GV. Approach of the systems to problem of individualization of training of fighters. Physical education of students, 2013; 17(5): 65-68. doi:10.6084/ m9.figshare.771109

10.Latyshev SV. Theoretical bases of individualization of training in wrestling. Physical education of students, 2013; 17(2): 45-48. doi:10.6084/m9.figshare.156379

11.Nagovitsyn RS. Conceptual framework of formation of personal physical culture of student based on mobile learning. Theory and Practice of Physical Culture, 2014;10:3.

12.Nagovitsyn RS, Rassolova EA, Senator SYu, Torbina II. Web portal design to prepare students for gto tests. Theory and Practice of Physical Culture, 2016;1:13.

13.Nagovitsyn RS, Rassolova EA, Sokolnikova EI, Senator SYu, Torbina II. Technology of system development of physical qualities of young people with regard to mobile learning. Theory and Practice of Physical Culture, 2015;11:32.

14.Nagovitsyn RS, Vladykina IV, Senator SYu. Training program to hit standards of all-russian sports complex «Ready for labour and defence» (GTO) based on mobile learning. Theory and Practice of Physical Culture, 2015;1:13.

15.Nagovitsyn RS, Volkov PB, Miroshnichenko AA. Planning of physical load of annual cycle of students', practicing cyclic kinds of sports, training. Physical education of students, 2017;21(3):126-133. doi:10.15561/20755279.2017.0305

16.Portnyagin II, Torgovkin VG, Nikolaev ND. Individualization of training process of student-freestyle wrestlers. Theory and Practice of Physical Culture, 2015;10:10.

17.Taymazov AB, Karelin AA, Tarakanov BI, Apoiko RN. Competitive wrestling as priority study field for research education school of P.F. Lesgaft National State University. Theory and Practice of Physical Culture, 2016;10:5.

18.Tropin YM. Comparative analysis of technical and tactical preparedness Greco-Roman style wrestler at the Olympic Games-2008 and the Olympic Games-2012. Physical education of students, 2013; 17(4): 92-96. doi:10.6084/ m9.figshare.663629

19.Tropin YN, Pashkov IN. Features of competitive activity of highly qualified Greco-Roman style wrestler of different manner of conducting a duel. Pedagogics, psychology, medical-biological problems of physical training and sports, 2015; 19(3): 64-68. doi:10.15561/18189172.2015.0310

20.Sawczyn S, Jagiełło W, Mishchenko VS, Fetisov VI. Dependence of work capacity recovery after strenuous training sessions upon individual predisposition of skilled wrestlers to work under different energy modes. Archives of Budo, 2015;11:197-207.

21.Chaabene H, Negra Y, Bouguezzi R, Mkaouer B, Franchini E, Julio U, et al. Physical and physiological attributes of wrestlers: an update. Journal of Strength and Conditioning Research. 2017;31(5):1411-1442.

22.Danilowicz-Szymanowicz L, Szwoch M, Ratkowski W, Gutknecht P, Zagozdzon P, Opielowska-Nwak B, et al. A $100 \mathrm{~km}$ Run Does Not Induce Persistent Predominance of Sympathetic Activity During 24-Hour Recovery in Amateur Male Athletes. Hellenic Journal of Cardiology. 2015;56(3):271-2.

23.Demirkan E, Koz M, Kutlu M, Favre M. Comparison of physical and physiological profiles in elite and amateur young wrestlers. Journal of Strength and Conditioning Research. 2015;29(7):1876-1883. doi:10.1519/jsc.0000000000000833

24.Eider J, Ahmetov, II, Fedotovskaya ON, Moska W, Cieszczyk P, Zarebska A, et al. CKM gene polymorphism in Russian and Polish rowers. Russian Journal of Genetics. 2015;51(3):31821.

25.Gierczuk D, Lyakh V, Sadowski J, Bujak Z. Speed of Reaction and Fighting Effectiveness in Elite Greco-Roman Wrestlers. Perceptual and Motor Skills. 2017;124(1):200213. doi:10.1177/0031512516672126

26.Gmiat A, Mieszkowski J, Prusik K, Prusik K, Kortas J, Kochanowicz A, et al. Changes in pro-inflammatory markers and leucine concentrations in response to Nordic Walking training combined with vitamin D supplementation in elderly women. Biogerontology 2017:1-14. doi:10.1007/s10522017-9694-8

27.Jagiello W, Kruszewski A. Morphological diversification of competitors training Greco-Roman style of wrestling. Archives of Budo. 2009;5:147-53. 
28.Jagiello W, Sawczyn S, Jagiello M. The subjective profile of positive health and survival abilities in women differing as to physical activity. Archives of Budo. 2012;8(4):219-24.

29.Jastrzebski Z, Zychowska M, Jastrzebska M, Prusik K, Prusik K, Kortas J, et al. Changes in blood morphology and chosen biochemical parameters in ultra-marathon runners during a 100-km run in relation to the age and speed of runners. International Journal of Occupational Medicine and Environmental Health. 2016;29(5):801-14. doi: 10.13075/ ijomeh.1896.00610

30.Khudolii OM, Ivashchenko OV, Iermakov SS, Rumba OG. Computer simulation of junior gymnasts' training process. Science of Gymnastics Journal. 2016;8(3):215-228.

31.Korobeynikov G, Mazmanian K, Korobeynikova L, Jagiello W. Psychophysiological states and motivation in elite judokas. Archives of Budo. 2010;6(3):129-36.

32.Kortas J, Kuchta A, Prusik K, Prusik K, Ziemann E, Labudda $\mathrm{S}$, et al. Nordic walking training attenuation of oxidative stress in association with a drop in body iron stores in elderly women. Biogerontology 2017: 1-8. doi:10.1007/s10522-0179681-0

33.Kostrzewa-Nowak D, Nowak R, Chamera T, Buryta R, Moska W, Cieszczyk P. Post-effort chances in c-reactive protein level among soccer players at the end of the training season. Journal of Strength and Conditioning Research. 2015;29(5):1399-405.

34.Kozina ZL, Iermakov SS, Kuzmin VA, Kudryavtsev MD, Galimov GJ. Change of Cortisol and Insulin Content in
Blood under Influence of Special Workability Recreation System for Students with High Motor Functioning Level. Research Journal of Pharmaceutical Biological and Chemical Sciences. 2016;7(2):1068-1077.

35.Kriventsova I, Iermakov S, Bartik P, Nosko M, Cynarski WJ. Optimization of student-fencers' tactical training. Ido Movement for Culture-Journal of Martial Arts Anthropology. 2017;17(3):21-30. doi:10.14589/ido.17.3.3

36.Nikooie R, Cheraghi M, Mohamadipour F. Physiological determinants of wrestling success in elite Iranian senior and junior Greco-Roman wrestlers. Journal of Sports Medicine and Physical Fitness. 2017;57(3):219-226. doi:10.23736/ s0022-4707.16.06017-5

37. Osipov AY, Kudryavtsev MD, Iermakov SS, Jagiello W. Criteria for effective sports selection in judo schools - on example of sportsmanship's progress of young judo athletes in Russian Federation. Archives of Budo. 2017;13:179-186.

38.Osipov AY, Kudryavtsev MD, Iermakov SS, Jagiello W. Topics of doctoral and postdoctoral dissertations devoted to judo in period 2000-2016-the overall analysis of works of Russian experts. Archives of Budo. 2017;13:1-10.

39.Podrigalo LV, Iermakov SS, Jagiello W. Special indices of body composition as a criterion of somatic development of martial arts practitioners. Archives of Budo Science of Martial Arts and Extreme Sports. 2017;13:5-12.

40.Sawczyn S, Mishchenko V, Moska W, Sawczyn M, Jagiello M, Kuehne T, et al. Strength and aerobic training in overweight females in Gdansk, Poland. Open Medicine. 2015;10(1):152-62.

Information about the authors:

Nagovitsyn R.S.: http://orcid.org/0000-0003-4471-0875; gto18@mail.ru; Glazov State Pedagogical Institute; Pervomaiskaya Street, 25, Glazov, 427620, Russia.

Volkov P.B.: http://orcid.org/0000-0003-0347-3084; pbvolk@mail.ru; Glazov State Pedagogical Institute; Pervomaiskaya Street, 25, Glazov,427620, Russia.

Miroshnichenko A.A.: http://orcid.org/0000-0002-2845-3437; ggpi@mail.ru; Glazov State Pedagogical Institute; Pervomaiskaya Street, 25, Glazov,427620, Russia

Tutolmin A.A.: http://orcid.org/0000-0002-6746-2985; tutolmin-lindt@yandex.ru; Glazov State Pedagogical Institute; Pervomaiskaya Street, 25, Glazov,427620, Russia.

Senator S.Yu.: http://orcid.org/0000-0002-0779-9199; s-senator@yandex.ru; Moscow Social Pedagogical Institute; Friedrich Engels Street, 75, Moscow, 105082, Russia.

Cite this article as: Nagovitsyn RS, Volkov PB, Miroshnichenko A.A, Tutolmin AA, Senator SYu. The influence of special graduated weight load in Greco-Roman wrestling on the growth of students' sports results. Physical education of students, 2017;21(6):294-301. doi:10.15561/20755279.2017.0606

The electronic version of this article is the complete one and can be found online at: http://www.sportedu.org.ua/index.php/PES/issue/archive

This is an Open Access article distributed under the terms of the Creative Commons Attribution License, which permits unrestricted use, distribution, and reproduction in any medium, provided the original work is properly cited (http://creativecommons.org/licenses/by/4.0/deed.en).

Received: 12.08 .2017

Accepted: 05.09.2017; Published: 08.12.2017 